\title{
Biodiesel from castor oil: a promising fuel for cold weather
}

\author{
Carmen Leonor Barajas Forero \\ Department of Hydraulic, Fluids and Thermal Sciences \\ Francisco de Paula Santander University \\ Avenida Gran Colombia No.12E-96 Cucuta (Colombia) \\ e-mail: clbarajas@bari.ufps.edu.co
}

\begin{abstract}
Ricinus communis is a species that belongs to the Euphorbiaceae family and it is commonly known as castor oil plant, and Palma Christi. This plant originates in Africa but it is found in both wild and cultivated states in all the tropical and subtropical countries of the world. In wild conditions this plant is well-adapted to arid conditions and is able to stand long periods of drought.

Results of transesterification experiments of castor oil with methanol are presented. The castor biodiesel has very interesting properties (very low cloud and pour points) that show that this fuel is very suitable for using in extreme winter temperatures.
\end{abstract}

Key words: castor oil, biodiesel, biofuels, transesterification, Ricinus communis

\section{Introduction}

Colombia must face a new stage in the development of its oil industry. After a decade in which oil reserves have shown a pronounced drop, it has become necessary to find new sources. However, the chances of finding oil wells of considerable size are becoming more and more limited. This situation has made it imperative to take a gamble with smaller oil fields that had once been deemed economically unviable. Moreover, it can be said that Colombia is not an oil-producing country but rather an oil-containing country whose new mission in oil exploration is to achieve self-sufficiency without having to import oil products in the near future [1].

Given what has been said, and taking into account the fluctuations in the oil industry it is essential that the country extend its interest toward new sources of energy. A relatively new alternative that is currently booming worldwide is fuel obtained from renewable resources or biofuel. Kann et al reports that the 1997 production of biodiesel was 550000 tons in Europe, 10000 tons in Malaysia, and 9000 tons in the United States. In the year 2000 the production of Europe increased to 1210000 tons. Overall the world's reported production increased approximately 2.2 times in three years [2]

Colombia has initiated its participation in the field of biofuel with the implementation of the 2001- 693 Law that dictates regulations for the use of fueling alcohols, as well as incentives for its production and utilization. This law also regulates the addition of bioethanol to automotive gasoline and diesel as a form of diminishing the impact of contaminating emissions.

Biodiesel is currently undergoing a phase of active research by several universities and organizations in Colombia. The national government created the Corporación para el Desarrollo Industrial de la Biotecnología y Producción Limpia (CORPODIB), which supports and undergoes research on alternative sources of energy. So far, its work has included the support of projects about the production of ethanol from sugars (bioalcohol) and the creation of a pilot plant for the production of biodiesel from cooking oils. The National University of Colombia in Medellín (Unalmed) and the University of Antioquia along with the Empresa Interamericana de Productos Químicos S.A. (Interquim) and funding from Colciencias, are currently developing a project that has as its objective the optimization of the production process of biodiesel from palm oil [3]. Although palm oil seems to be a promising source of biodiesel in Colombia because of the productive capacity already in place, it was decided to explore the production of the biofuel from castor oil. Since the source plant is commonly found in a wild state in many parts of the country its cultivation has a competitive advantage with respect to other oily plants.

\section{A. Castor Oil Plant (Ricinus communis)}

Ricinus communis is a species that belongs to the Euphorbiaceae family and it is commonly known as castor oil plant, and Palma Christi. This plant originates in Africa but it is found in both wild and cultivated states in all the tropical and subtropical countries of the world. In wild conditions this plant is well-adapted to aridconditions and is able to stand long periods of drought.

Ricinus communis plants can present precocious, median and delayed cylces [4]. The precocious cycle is that in which flowering occurs about 45 days after sowing. The median cycle presents flowering at an intermediate time between the precocious and delayed cycle, which has a flowering time of 90 to 120 days after sowing. 


\section{B. Castor Oil}

Castor oil is extracted from the seeds of Palma Christi. Seeds are approximately $46 \%$ oil. This oil is highly viscous, its coloration ranges from a pale yellow to colorless, it has a soft and faint odor and a highly unpleasant taste.

Castor oil dissolves easily in alcohol, ether, glacial acetic acid, chloroform, carbon sulfide, and benzene. Its made up of triglycerides: $91-95 \%$ ricinoleic acid, $4-5 \%$ linoleic acid, and 1-2\% palmitic and stearic acids. Besides being used as a laxative, castor oil is widely used in the industrial field because of its many properties. In the textile industry, castor oil is used for moisturizing and removal of grease in fabrics, and for the manufacturing of waterproof fabrics. In the steel industry, it is used in cutting oils and lubricants for steel lamination at high temperatures and it is also used in other liquids that are necessary for steel work. The automotive industry uses castor oil for the production of high performance motor oil and braking fluids. Moreover, it is also employed as a softener in the tanning industry and in the production of fluids for hydraulic devices, artificial leather, varnish, paint, linoleum, insulators, powder, fatty acids, enzymes, as a moisturizer for stationary and insecticides; additionally it can be used as a raw material for the fabrication of plastics.

\section{Biodiesel}

Biodiesel fuel can be defined as medium length (C16 \pm C18) chains of fatty acids, and is comprised mainly of mono-alkyl fatty acid esters. Biodiesel fuel has the benefits of being non-toxic, biodegradable and essentially free of sulphur and carcinogenic ring components [5].

Considerable research has been done on vegetable oils as diesel fuel. That research includes palm oil, soybean oil, sunfower oil, coconut oil, rapeseed oil and tung oil [6]. Not much information about castor oil as a biodiesel is found.

Soy biodiesel is predominantly used in the United States, while canola biodiesel is dominant in Europe [7].

Although biodiesel has many environmental advantages it also has some performance drawbacks. In cold conditions the behavior of the biofuels normally is even worse than that of petroleum diesel. At low temperatures biodiesel and diesel form wax crystals that can restrict the flow in a vehicle fuel system clogging fuel lines and filters. Castor oil biodiesel exhibits different operation conditions.

\section{A. Cold flow properties}

Cloud point and pour point are important parameters for low temperature operation. Pour point refers to the temperature at which the amount of wax out of solution is sufficient to gel the fuel and indicates the lowest temperature at which the fuel can flow. Cloud point means the temperature at which wax first become visible when the fuel is cooled [8].

Pour and cloud temperatures of biodiesel from different vegetable oils are shown in Table 1 . They are relatively high making the use of additives necessary to improve its performance.

\section{B. Biodiesel production}

A minimal content of water and free fatty acids in oil or fat is important for obtaining optimal results in the transesterification process. The existing water promotes the decomposition of esters in glycerol and fatty acids, which, combined with the fatty acids already free, saponify with the basic catalyst (soap formation) thus decreasing the efficiency of the transesterification. Feuge and Grose highlighted the importance of using dry oils and a fatty acid content of less than $0.5 \%$ by weight [9]. A basic catalyst is used in the transesterification of triglycerides with a low content of fatty acids. However, if the water and fatty acid contents are high, either an acid catalyst must be used or two transesterifications must be done, one with an acid catalyst and another with a basic one.

Reaction rate increases with reaction time. Freedman et al performed trials with peanut, soy, and sunflower oils at $60^{\circ} \mathrm{C}$ using methanol and sodium methoxide as a catalyst and found that around $80 \%$ of the conversion of esters occurs within the first few minutes of the reaction and after an hour it reaches a range of about 93-98\% [10]. When an acid catalyst is used, reaction time can be much longer. The temperature of the transesterification, its catalyst and quantity, the alcohol and its moral relation with the triglyceride depends on the oil or fat that is being used. Bradshaw and Meuly found that the practical range of the molar ratio between methanol and a vegetable oil is 3.3 to $5.5: 1$ [11].

In our research we carried out transesterification by reacting castor oil with methanol in the presence of a basic catalyst $(\mathrm{NaOH})$. Castor oil was supplied by Leon Laboratories (Colombia) and the biodiesel fuel was processed in a batch type reactor. The catalyst was dissolved into the alcohol by vigorous stirring in a small reactor. The oil was transferred into the reactor and then the catalyst/alcohol mixture was poured into the oil and the final mixture stirred vigorously for two hours. Two phases were obtained at the end of the reaction: ester and crude glycerol. Biodiesel was observed in the top one and glycerine, a subproduct of the process, was observed in the lower one. Since the castor oil used as a raw material presented some humidity $(0.2 \%)$ soaps became present but they were removed by a washing process. It is important to note that these impurities may cause problems in the operation of the engine because of the formation of coal dust. Properties of biodiesel were tested according to ASTM D 6751 standard. 


\section{Results}

The efficiency in the process for the production of biodiesel was in the range of $80-82 \%$. Table 1 shows a comparison between the properties of petroleum diesel and the boidiesel obtained in the laboratory. It also presents data pertinent to the mixture of petroleum diesel and biodiesel in the following fashion:

Petroleum diesel (90\%)- biodiesel (10\%) : B10

Petroleum diesel (80\%)- biodiesel (20\%) : B20
Petroleum diesel (0\%)- biodiesel (100\%) : B100

Castor oil properties indicate a very low pour and cloud points which make this biofuel a good alternative in winter conditions. Also, mixtures of 20 (B20) and 10 (B10) percent biodiesel-petroleum diesel showed good flow properties. It indicates that castor oil biodiesel also could be used as petroleum diesel additive improving both environmental and flow behavior of the mineral fuel.

TABLE 1. - Biodiesel properties. Different vegetable oil sources.

\begin{tabular}{|l|l|l|l|l|l|}
\hline Fuel & Flash Point $\left({ }^{0} \mathrm{C}\right)$ & Sp. Gr. & HHV $(\mathrm{MJ} / \mathrm{Kg})$ & Cloud Point $\left({ }^{0} \mathrm{C}\right)$ & $\begin{array}{l}\text { Pour Point } \\
\left({ }^{0} \mathrm{C}\right)\end{array}$ \\
\hline Soy $\mathrm{ME}^{+}$ & 131 & 0.885 & 40.4 & -0.5 & -3.8 \\
\hline Rape $\mathrm{ME}^{+}$ & 170 & 0.883 & 40.7 & -4.0 & -10.8 \\
\hline Soy EE & 160 & 0.881 & 40.0 & -1.0 & -4.0 \\
\hline Rape EE & 185 & 0.876 & 40.5 & -2.0 & -15.0 \\
\hline TallowME & 117 & 0.876 & 40.2 & 13.9 & 9 \\
\hline Canola ME $^{++}$ & 163 & 0.88 & 39.9 & 1 & -9 \\
\hline
\end{tabular}

${ }^{+}[8]^{++}[12]$

TABLE 2. Castor oil biodiesel [13]

\begin{tabular}{|l|l|l|l|l|l|}
\hline Properties & Units & $\begin{array}{l}\text { Petroleum } \\
\text { diesel }\end{array}$ & B10 & B20 & B100 \\
\hline Sp. Gr. & & 0.8610 & 0.8643 & 0.8703 & 0.9268 \\
\hline Density & $\mathrm{kg} / \mathrm{m}^{3}$ & 861.0 & 864.3 & 870.3 & 926.8 \\
\hline $\begin{array}{l}\text { Kinematic } \\
\text { viscosity }\end{array}$ & $\mathrm{mm}^{2} / \mathrm{s}$ & 3.81 & 4.54 & 4.97 & 15.98 \\
\hline Flash point & ${ }^{\circ} \mathrm{C}$ & 68.3 & 85.3 & 88.7 & 190.7 \\
\hline Heating value & $\mathrm{kJ} / \mathrm{kg}$ & 47216.4 & 44427.6 & 44780.4 & 37900.8 \\
\hline $\begin{array}{l}\text { Copper strip } \\
\text { corrosion }\end{array}$ & & $1 \mathrm{a}$ & $1 \mathrm{a}$ & $1 \mathrm{a}$ & $1 \mathrm{~b}$ \\
\hline Carbon residue & $\%$ masa & 0 & 0.009 & 0.007 & 0.037 \\
\hline Cloud point & ${ }^{\circ} \mathrm{C}$ & & -5 & -7 & -23 \\
\hline Pour point & ${ }^{\circ} \mathrm{C}$ & -6 & -26 & -30 & -45 \\
\hline
\end{tabular}

\section{A. Trials in stationary engines}

Performance trials for biodiesel and biodiesel mixtures were carried out at the test ground for internal combustion engines in the engine laboratory of the Universidad Francisco de Paula Santander.

The engine ignited and operated normally with all the combustibles that were tested. The curves developed by each combustible showed the same trend. Petroleum diesel presented the highest torque in all rpm values, even though the difference was very small when compared to the mixtures (B10, B20) and pure biodiesel (B100). Power tests displayed a similar behavior.

When petroleum diesel was compared to the B10, B20, and B100 mixtures, it was observed that B100 showed the highest combustible expenditure. This difference is possibly determined by the higher density of biodiesel since there will be a higher quantity of mass available to react and release its energy for any given volume of injected combustible. For this reason, it is presumed that a compensation in the difference of caloric power occurs, allowing for a negligible difference in torque and power when compared to petroleum diesel.

\section{Conclusions}

The transesterification process of castor oil is carried out with a basic catalyst and a single reaction step is required because of its favorable acidity level. Therefore, in a large-scale process it would be less costly than chemical processes with other oils with a higher acidity level.

The properties of the B100 combustible and its B10 and B20 mixtures are comparable to those of petroleum diesel and acceptable within what is specified for biodiesel in the ASTM D 6751 standard (with the exception of viscosity and humidity in $\mathrm{B} 100$ ). 
It was found that viscosity was higher as the proportion of biodiesel in the mixtures increased. However, this event does not affect the atomization characteristics.

B100 has the highest flash and ignition points. Increasing the proportion of biodiesel in the mixture elevates its flash and ignition temperatures. A higher flash point translates into a higher level of safety in combustible transport and storage.

It is importante to highlight that both cloud and pour points decline as more biodiesel is added to petroleum diesel. This implies a higher level of stability at lows temperatures, making B100 an ideal combustible for those regions with extreme seasonal weather as it doesn't require any kind of additives to conserve its fluidity.

Aditionally to the combusting properties that were analyzed, biodiesel displays ability as a solvent, which allows it to remove any impurities, thus preventing the formation of sediments that could potentially obstruct pipes and filters. In a similar fashion, biodiesel has a higher cooling capacity, as it presented an increase of $18.2 \%$ in return temperature when compared to petroleum diesel. This aspect is key in the conservation of the engine components.

Considering the technical features presented here, B100 and its mixtures can be employed as diesel fuel. The massification of castor oil biodiesel is advisable taking into account that it is a renewable resource and that because of its biodegradability and lower emissions it presents a favorable impact on the environment. Given the widespread presence and ease of cultivation of the castor oil plant it could be used in crop substitution programs turning it into a factor that promotes growth in many regions affected by severe economic problems.

\section{Acknowledgement}

This work was partially supported by the Research Office of Francisco de Paula Santander University.

\section{References}

[1] Tovar, Líela y Téllez, Mauricio. We are looking for oil and gas. Interview with ECOPETROL vicepresident.Oil Setter.Vol. 107, (Nov. 2003 - Jan. 2004); p. 10.

[2] Kann J., Rang H., , and Kriis J.. Advances in biodiesel fuel research. Proc. Estonian Acad. Sci. Chem., 51, 2, p.75-117 (2002).

[3]COLCIENCIAS. 2004. Agenda y Novedades. http://www.colciencias.gov.co/agenda/pn113.html

[4] Krung and Teixeira Mendes Y. Improving of mamoneira, cited by Mazzani, Bruno. Oil plants. Agronomic Research Center of Agricultural Ministery. Central University of Venezuela. Agronomy department. Barcelona. Salvat, 1963. p. 150.
[5] Yamane, K., Ueta, A. and Shimamoto, Y. Influence of physical and chemical properties of biodiesel fuels on injection, combustion and exhaust emission characteristics in a direct injection compression ignition engine. Int J Engine Research 2, 4, 249261.(2001).

[6] Ma, F., Hanna M.A. Biodiesel production: a review. Bioresource Technology 70, 1-15.(1999).

[7] Kinast, J.A..Production of Biodiesels from Multiple Feedstocks andProperties of Biodiesels and Biodiesel/Diesel Blends.Final Report. National Renewable Energy Laboratory. (2003).

[8] Prakash, C.B.. A Critical Review of Biodiesel as a Transportation Fuel in Canada. Environment Canada.(1998).

[9] Kinast, J.A..Production of Biodiesels from Multiple Feedstocks andProperties of Biodiesels and Biodiesel/Diesel Blends.Final Report. National Renewable Energy Laboratory. (2003).

[10] Freedman, B., Pryde, E.H., Mounts, T.L 1999. Variables affecting the yields of fatty esters from transesterified vegetable oils, citado por MA, Fangrui and Hanna, Op. cit., p. 10.

[11] Bradshaw, G.B. y And Meuly, W.C. 1999. Preparation of detergents, citado por Ma, Fangrui and Hanna, Milford. Biodiesel production : a review. Bioresource Technology. Vol. 70; p. 9.

[12] De Winne, T. Biofuels for Sustainable Transport. http://journeytoforever.org/biodiesel_comparison.ht ml. October 12, 2004.

[13] Flórez J.P. Nieto, N.A., Londoño, N.Y., Barajas, C.L. Proceso Experimental de Producción y Operación del Biocombustible obtenido partir del Aceite de Ricino. Tesis. Universidad Francisco de Paula Santander. (2004). 